\title{
Can firm environmental performance affect stock liquidity: Evidence from Chinese A share market
}

\author{
Jianhua $\mathrm{Ye}^{1, *}$, Shangyi Bai ${ }^{2}$ \\ ${ }^{1}$ School of Accounting, Henan University of Economic and Law, Zhengzhou, China \\ ${ }^{2}$ Swansea Business Campus, University of Wales Trinity Saint David, Swansea, UK
}

\begin{abstract}
CHINDICES' environmental performance rating was used to proxy for the environmental performance of the sample companies in Chinese stock market. Portfolios analysis method and Ordinary Least Square(OLS)method was used to examine the relationship between the environmental performance and stock liquidity. Results based on the investigations indicated that firm environmental performance have a negative and significant relationship with the level of stock liquidity in whose firms with high environmental performance ratings, whereas this relationship is positive and significant in whose firms with low environmental performance rating $\mathrm{s}$, and the relationship between environmental performance and stock liquidity is a inverted-U shape. This research enrich the researches on determinants of stock liquidity, and is also helpful for firms to comprehensive evaluate their environmental related decision making.
\end{abstract}

\section{INTRODUCTION}

As the society pay more and more attention on firm environmental performance(EP), investigating the consequences of EP become more important. Most of the prior researches investigated how EP affect firm financial performance(FP) based on instrumental stakeholder theory, neoclassical economics theory, agency theory, trade-off theory。 But the results of these empirical researches are mixed, including positive, negative, neutral relationship(Ben Lahourlet al., 2019) [1], or inverted-U shape caused by marginal benefits decreasing and marginal cost increasing when firm enforce environment protection activities(Salzmann et al., 2005) [2]. On the other aspect, stock liquidity are the basis of arbitraging activity,risk management, asset pricing, cost of capital and efficient resource allocation. During financial crisis and in the uncertainty market, lack of liquidity bring potential big damage. As a result, stock liquidity become the focus of many researchers and practicers. So, it is necessary to investigate the determinants of stock liquidity. Existing researches prove that maco-variables, stock trading regulation, investor protection regulation, information environment, behavioral factors, investor sentiment and firm characteristics are important determinants of stock liquidity. But, there is no research to investigate how EP affect stock liquidity.

\footnotetext{
${ }^{*}$ Corresponding author: yejianhua99@sina.com
}

\section{Theory background}

Firm EP affect stock liquidity may through affecting firm FP and letigate risk. According to the Instrumental stakeholder theory, long term environment target can Establish one kind of dynamic ability that can reduce environment uncertainty and attract more shareholders. This theory is the combination of legitimization theory and agency theory, and this theory focus on the contract between managers and stakeholder and believe that trust and cooperation can help firm obtain competitive advantage(Jones, 1995) [3]. Such as, firm can gain more earnings, improve customer loyalty, and can more efficiently deal with external demand change, and can reduce risk of litigation, by satisfy stakeholders' environment protection demand(Endrikat et al., 2014) [4].

In Chinese special background, good EP can affect firm stock liquidity by reducing risk of being litigated, and main by affecting firm FP. Aspara(2013) [5] analyzed the characteristics of individual investors' trading behaviors and found that firm's managerial quality can affect such decisions. In firms with stronger managerial quality related asset liquidity and profitability, stock liquidity is always more stronger(Correia and Amaral, 2014) [6]. Profitability is the key factor that market participants considering when making trading decisions. Kim and Verrecchia(1994) [7] found that investors can make reaction to information disclosure and trading volume is increased significantly around earnings announcement periods.Correia and Amaral(2014) [6] prove that return of sale is positively 
with stock liquidity. Alnaif(2014) [8] prove that earnings per share is positively with stock liquidity. Based on the foundlings above, we can conclude that EP-FP relation is a inverted-U shape, and the relationship of FP with stock liquidity is positive. So, we can deduce that the relationship of firm EP with stock liquidity is inverted-U shape.

Hypothesis: The relationship between environmental performance and stock liquidity is a inverted-U shaped.

\section{METHODOLOGY AND DATA}

Our study sample constitutes of listed companies in Chinese A share market in 2019. The choice of sample period is based on the availability of all variables and EP ratings. We obtain stock trading data and financial statement information form RESSET database provider, and obtain EP ratings data from WIND database.

Dependent Variable: level of stock liquidity proxy by calculated by individual stock daily trading return within one year, and this variable is indexed by AMH.

Control variables: The control variables we choose including return of asset, financial leverage, return of asset, price divided by book value, price divided by earnings per share, price divided by revenue and industry effect.

This paper use portfolio analysis, ordinary linear regression method, and regression in sub-sample to investigate how EP affect stock liquidity.

\section{EMPIRICAL RESULTS}

\subsection{Portfolios Analysis}

Constructing nine portfolios based on EP ratings and calculating summary statistics of stock liquidity in each portfolios, and the results are presented in table 1 .

Table 1 presents that stock liquidity of portfolios is increasing as EP rating is decreasing in the AAA, AA and $\mathrm{A}$ EP rating portfolios.In the five lower EP rating firms, from BBB EP rating to CC EP rating, stock liquidity is increasing as EP rating is increasing. Value of $\mathrm{AMH}$ in $\mathrm{C}$ EP rating firm is relatively high, and approximate with that value in B EP rating firms.

Table 1. Summary statistics of AMH in each of the 9 EP ratings Portfolios

\begin{tabular}{|c|c|c|c|c|c|c|c|}
\hline EPJ & $\mathbf{N}$ & $\mathbf{L}$ & $\mathbf{M E}$ & MED & $\mathbf{H}$ & SK & KT \\
\hline AAA & 27 & 0.017 & 0.043 & 0.040 & 0.062 & 0.528 & -0.477 \\
\hline AA & 153 & 0.011 & 0.033 & 0.024 & 0.050 & 0.966 & -0.085 \\
\hline A & 226 & 0.009 & 0.031 & 0.022 & 0.045 & 1.276 & 1.474 \\
\hline BBB & 298 & 0.009 & 0.029 & 0.020 & 0.040 & 1.594 & 2.537 \\
\hline BB & 191 & 0.018 & 0.041 & 0.036 & 0.057 & 1.347 & 2.555 \\
\hline B & 1026 & 0.024 & 0.046 & 0.039 & 0.064 & 0.869 & 0.343 \\
\hline CCC & 1207 & 0.023 & 0.047 & 0.041 & 0.064 & 0.913 & 0.708 \\
\hline CC & 90 & 0.034 & 0.056 & 0.052 & 0.073 & 0.606 & 0.057 \\
\hline C & 22 & 0.022 & 0.042 & 0.037 & 0.051 & 1.267 & 1.642 \\
\hline
\end{tabular}

In summary, the evidence from table one prove that stock liquidity is decreasing as EP rating is decreasing in firms with good EP, and stock liquidity is increasing as EP rating is increasing in firms with bad EP.

\subsection{OLS regression results analysis}

Regression analysis can more precisely analyze how EP affect stock liquidity after controlling the known factors affecting stock liquidity. Table 2 provide the regression results.

When can see that the estimated coefficients of dummy variable AAA, AA, and A are $0.008,0.000$ and -0.005 (Significant at the 99 percent levels of confidence). This results indicates that high EP rating in firms with good EP can reduce stock liquidity on some extent. When the independent dummy variable are from BBB to CC separately, the corresponding estimated coefficients of each dummy variable are -0.004(Significant at the 99 percent levels of confidence), $-0.002,0.003$ (Significant at the 99 percent levels of confidence), 0.000 and 0.006 (Significant at the 95 percent levels of confidence). These evidence indicates that high EP rating in firms with bad EP can increase stock liquidity.

In summary, the evidences from regression analysis are consistent with the evidences obtained in the portfolios analysis, and all these evidences prove that the relationship between EP and stock liquidity is inverted- $U$ shape. Comparing the scope and direction of the estimated coefficients of the highest and lowest dummy variable within each sub-sample can provide us more evidence on how EP affect stock liquidity in firms with different level of EP. 
Table 2. OLS regression results in the whole sample

\begin{tabular}{|c|c|c|c|c|c|c|c|c|c|}
\hline Inter & $\begin{array}{c}0.272 * * * \\
(29.90)\end{array}$ & $\begin{array}{c}0.272 * * * \\
(29.72)\end{array}$ & $\begin{array}{c}0.269 * * * \\
(29.52)\end{array}$ & $\begin{array}{c}0.266^{* * * *} \\
(28.70)\end{array}$ & $\begin{array}{c}0.272 * * * \\
(29.88)\end{array}$ & $\begin{array}{c}0.266^{* * * *} \\
(28.84)\end{array}$ & $\begin{array}{c}0.272 * * * \\
(29.62)\end{array}$ & $\begin{array}{c}0.271 * * * \\
(29.74)\end{array}$ & $\begin{array}{c}0.272 * * * \\
(29.87)\end{array}$ \\
\hline AAA & $\begin{array}{l}0.008 \\
(1.31)\end{array}$ & & & & & & & & \\
\hline AA & & $\begin{array}{l}0.000 \\
(0.15)\end{array}$ & & & & & & & \\
\hline A & & & $\begin{array}{c}-0.005 * * \\
(-2.74)\end{array}$ & & & & & & \\
\hline BBB & & & & $\begin{array}{c}-0.004^{* *} \\
(-2.69)\end{array}$ & & & & & \\
\hline BB & & & & & $\begin{array}{l}-0.002 \\
(-0.69)\end{array}$ & & & & \\
\hline B & & & & & & $\begin{array}{c}0.003 * * * \\
(3.04)\end{array}$ & & & \\
\hline $\mathrm{CCC}$ & & & & & & & $\begin{array}{l}0.000 \\
(0.20)\end{array}$ & & \\
\hline $\mathrm{CC}$ & & & & & & & & $\begin{array}{c}0.006^{* *} \\
(1.94)\end{array}$ & \\
\hline $\mathrm{C}$ & & & & & & & & & $\begin{array}{l}-0.002 \\
(-0.45)\end{array}$ \\
\hline Adj_R2 & 28.46 & 28.42 & 28.59 & 28.58 & 28.43 & 28.63 & 28.42 & 28.50 & 28.43 \\
\hline $\mathrm{N}$ & 3208 & 3208 & 3208 & 3208 & 3208 & 3208 & 3208 & 3208 & 3208 \\
\hline F & 54.57 & 54.47 & 54.91 & 54.89 & 54.50 & 55.01 & 54.47 & 54.69 & 54.48 \\
\hline
\end{tabular}

Notes: $*, * *, * * *$ Significant at the 90,95 and 99 percent levels of confidence, respectively; Estimated results of the controls variables are omitted to save space.

\subsection{OLS regression results analysis in the sub-sample}

Table 3 present OLS regression results. The regression results in high EP ratings show that the coefficients of AAA and A are 0.008 and -0.003 in the first and second step, and the corresponding two coefficients are opposite in the third step. These evidence prove that the relationship of EP and stock liquidity is negative in firms with good EP. In the sub-sample with low firm EP, the coefficients of $\mathrm{BBB}$ and $\mathrm{CC}$ in the first and second step are -0.005 and 0.007 and significant at $99 \%$ and $95 \%$ level of confidence, respectively. In the third regression results, the coefficients and the corresponding significance of BBB and CC are similar with that in the first and second steps. All these evidence above prove that EP have positive effect on stock liquidity in firms with low EP.

In summary, regression results in sub-sample prove that the relationship between stock liquidity in firms with high EP is negative, but this relationship is positive in firms with low EP.

Table 3. Regression results with each sub-sample

\begin{tabular}{|c|c|c|c|c|c|c|}
\hline \multirow[b]{2}{*}{ Inter } & \multicolumn{3}{|c|}{ High EP rating firms } & \multicolumn{3}{|c|}{ Low EP rating firms } \\
\hline & $\begin{array}{c}0.309 * * * \\
(14.11)\end{array}$ & $\begin{array}{c}0.312^{* * *} \\
(14.16)\end{array}$ & $\begin{array}{c}0.311^{* * *} \\
(14.08)\end{array}$ & $\begin{array}{c}0.269 * * * \\
(25.47)\end{array}$ & $\begin{array}{c}0.277 * * * \\
(26.93)\end{array}$ & $\begin{array}{c}0.269 * * * \\
(25.40)\end{array}$ \\
\hline AAA & $\begin{array}{l}0.008 \\
(0.65)\end{array}$ & & $\begin{array}{l}0.008 \\
(0.64)\end{array}$ & & & \\
\hline A & & $\begin{array}{l}-0.003 \\
(-0.73)\end{array}$ & $\begin{array}{l}-0.003 \\
(-0.73)\end{array}$ & & & \\
\hline BBB & & & & $\begin{array}{c}-0.005^{* * *} \\
(-3.08)\end{array}$ & & $\begin{array}{c}-0.005 * * * \\
(-3.03)\end{array}$ \\
\hline
\end{tabular}




\begin{tabular}{|c|c|c|c|c|c|c|}
\hline CC & & & & & $\begin{array}{c}0.007^{* *} \\
(2.14)\end{array}$ & $\begin{array}{c}0.007^{* *} \\
(2.07)\end{array}$ \\
\hline Adj_R2 & 42.24 & 42.25 & 42.16 & 26.86 & 26.73 & 26.94 \\
\hline N & 405 & 405 & 405 & 2826 & 2826 & 2826 \\
\hline F & 15.10 & 15.11 & 14.42 & 44.24 & 43.96 & 42.69 \\
\hline
\end{tabular}

Notes: *,**,**Significant at the 90,95 and 99 percent levels of confidence, respectively; Estimated results of the controls variables are omitted to save space.

\section{Conclusions}

Most of the existing researches investigate how firm EP affect firm financial performance, but the research investigating how firm EP affect stock liquidity, which is the core of market efficiency, is rare. This paper induce the hypothesis on the relationship between EP and stock liquidity based on the theoretical analysis. And then, this paper conduct the empirical analysis using portfolio analysis, regression analysis in the whole and sub-sample to test the hypothesis. The conclusions include: the relationship between EP and stock liquidity is nonlinear; level of firm EP have negative impact on stock liquidity in firms with high level of EP; level of firm EP have positive impact on stock liquidity in firms with low level of EP.

\section{References}

1. B. B. Lahouel, B. Gaies, Y. B. Zaied, A. Jahmane, J. Clea. Prod. 230, 352-364(2019).

2. O.Salzmann, A.Ionescu-Somers, U.Steger, Euro. Mana. J. 23, 27-36( 2005).

3. T. M. Jones, Acad. of Mana. Revi. 20, 404437(1995).

4. J. Endrikat, E. Guenther, H. Hoppe, Euro. Mana. Jour. 32, 735-751 (2014).

5. J. Aspara, J. of Beha. Fina. 14, 195-212(2013).

6. L. F. Correia, H. F. Amaral, Bbr. Busi. Revi. 11, 75-97(2014).

7. O. Kim, R. E. Verrecchia, J. of Acco, \& Econ.17, 41-67(1994).

8. K. Alnaif, Asi. Econ. and Fina. Revi. 5, 1894-1905(2014). 